\title{
30. OXYGEN ISOTOPE RATIOS OF INTERSTITIAL WATERS FROM THE NANKAI TROUGH AND THE JAPAN TRENCH, LEG $87^{1}$
}

\author{
Yukihiro Matsuhisa, Geological Survey of Japan \\ and \\ Ryo Matsumoto, Geological Institute, University of Tokyo ${ }^{2}$
}

\section{INTRODUCTION}

Chemical and isotopic compositions of interstitial waters are indispensable data for discussing diagenetic processes of marine sediments. In a closed system, chemical and isotopic compositions of interstitial waters are modified by reaction with surrounding minerals. At the same time, the compositions of newly formed minerals are controlled by the compositions of coexisting interstitial waters. Oxygen isotope composition $\left({ }^{18} \mathrm{O} /{ }^{16} \mathrm{O}\right.$ ratio) is of special interest in this respect because oxygen isotope fractionation between minerals and water is very sensitive to temperature, and the modification of ${ }^{18} \mathrm{O} /$ ${ }^{16} \mathrm{O}$ ratios of interstitial waters depends upon surrounding rock types and kinds of reactions involved. Lawrence and others $(1975 ; 1979)$ observed a systematic decrease with depth in the ${ }^{18} \mathrm{O} /{ }^{16} \mathrm{O}$ ratio of interstitial waters in DSDP cores and ascribed it to the alteration of ${ }^{18} \mathrm{O}$-poor volcanic material to ${ }^{18} \mathrm{O}$-rich clay minerals. On the other hand, recrystallization of ${ }^{18} \mathrm{O}$-rich biogenic opal or carbonates at elevated temperatures would increase the ${ }^{18} \mathrm{O} /$ ${ }^{16} \mathrm{O}$ ratios of interstitial waters (Murata et al., 1977; Elderfield et al., 1982).

In the present paper, we report preliminary results on the ${ }^{18} \mathrm{O} /{ }^{16} \mathrm{O}$ ratios of the interstitial waters of the DSDP cores taken from subduction-related trenches near Japan: Sites 582 and 583 at the Nankai Trough off southwestern Japan, and Site 584 at the Japan Trench off northern Honshu (Fig. 1), where thick piles of young sediments have accumulated. Special attention was paid to any differences in isotopic behavior of interstitial waters with different surrounding lithology, the details of isotopic variation of interstitial waters in young, unconsolidated sediments, and the effects of sedimentary structural disturbance on interstitial waters.

\section{SAMPLES AND EXPERIMENTS}

Site 582 is located in the undeformed sediments of the trench floor, and Site 583 is in the stratigraphically equivalent but deformed sediments in the basal thrust sheet underlying the landward slope of the Nankai Trough (Karig et al., 1983). Site 584 is located on or slightly landward of the midslope terrace of the Japan Trench (Karig et al., 1983). The sediments recovered at Sites 582 and 583 consist of Quaternary turbidites and hemipelagic clays, muds, and silts, whereas those

\footnotetext{
${ }^{1}$ Kagami, H., Karig, D. E., Coulbourn, W. T., et al., Init. Repts. DSDP, 87: Washington (U.S. Govt. Printing Office).

2 Addresses: (Matsuhisa), Geological Survey of Japan, 1-1-3 Yatabe-Higashi, Ibaraki 305 Japan; (Matsumoto) Geological Institute, University of Tokyo, Hongo, Tokyo 113 Japan.
}

at Site 584 are characterized by diatomaceous muds and mudstones of Pliocene to Miocene times (Leg 87 Scientific Party, 1983).

At Site 582, eight interstitial water samples taken for isotope analyses represent a $674.8-\mathrm{m}-$ long stratigraphic column. At Site 583, eight holes were drilled across the landward slope of the Nankai Trough; Holes $583,583 \mathrm{E}, 583 \mathrm{~F}$, and $583 \mathrm{G}$ penetrated to a depth of $450 \mathrm{~m}$, just short of the basal thrust; Hole $583 \mathrm{~A}$ drilled $400 \mathrm{~m}$ farther landward on a structural terrace; and Holes 583B, 583C, and 583D constituted the uppermost part of a hole through the toe of the thrust (Leg $87 \mathrm{Sci}-$ entific Party, 1983; Karig et al., 1983). Twenty-nine interstitial waters were recovered from these cores. Of those, 18 samples were analyzed for oxygen isotopes (except for Holes 583A and 583E). At Site 584, 20 interstitial waters were recovered to a depth of $590 \mathrm{~m}$, and 15 were analyzed for oxygen isotopes.

Interstitial waters were recovered from core segments 10 to $15 \mathrm{~cm}$ in length. The sediment was removed and placed in a hydraulic squeezer, and the squeezed samples set aside for isotopic analyses were immediately sealed in plastic tubes.

Oxygen isotope analyses were preformed using the $\mathrm{CO}_{2}-\mathrm{H}_{2} \mathrm{O}$ equilibration method of Epstein and Mayeda (1953) for 0.5-to-2.0-ml aliquots of interstitial waters. Correction was made for a variable $\mathrm{CO}_{2-}$ to- $\mathrm{H}_{2} \mathrm{O}$ ratio in the equilibration. The ${ }^{18} \mathrm{O} /{ }^{16} \mathrm{O}$ ratios of the samples are reported in terms of the $\delta$-notation relative to International Atomic Energy Agency standard mean ocean water (SMOW). A single determination was made for each sample in the present study. Experimental error in normal procedures is smaller than $\pm 0.1 \%$. The measurements of the water reference samples in our laboratory at the Geological Survey of Japan are presented elsewhere (Gonfiantini, 1984).

\section{RESULTS AND DISCUSSION}

The $\delta^{18} \mathrm{O}$ values of the interstitial waters at Leg 87 sites range from -1.42 to $+0.61 \%$ (Table 1 ; Figs. $2,3,4$ ). The $\delta^{18} \mathrm{O}$ values decrease with depth at a virtually constant rate except for the holes at Site 583 . The ${ }^{18} \mathrm{O} /{ }^{16} \mathrm{O}$ gradient is $-0.19 \% / 100 \mathrm{~m}$ at Site 582 , whereas it is $-0.26 \% / 100 \mathrm{~m}$ at Site 584 . The ${ }^{18} \mathrm{O} /{ }^{16} \mathrm{O}$ decrease, which correlates with the decrease in $\mathrm{Mg}^{2+}$ concentration (the $\mathrm{Mg}^{2+}$ gradient is $-2.7 \mathrm{~m}$ mole/l per $100 \mathrm{~m}$ at Site 582 , and $-4.7 \mathrm{~m}$ mole/1 per $100 \mathrm{~m}$ at Site 584 ; see site chapters, Sites 582,583 , and 584 this volume), is readily interpreted as a result of exchange reaction with clay minerals (Lawrence et al., 1975; 1979). The ${ }^{18} \mathrm{O} /{ }^{16} \mathrm{O}$ gradients obtained in the present study are three or four times smaller than those of Lawrence and others (1975), probably because of the abundance of volcanic material and its alteration to clay minerals in the latter. The relatively older ages of the sediments studied by Lawrence and others (1975) (Miocene to Oligocene versus Quaternary to Miocene in the present study) may also have enlarged the ${ }^{18} \mathrm{O} /{ }^{16} \mathrm{O}$ gradients.

Although the diatomaceous muds at Site 584 contrast with the clay-rich sediments at Site 582 , no significant 

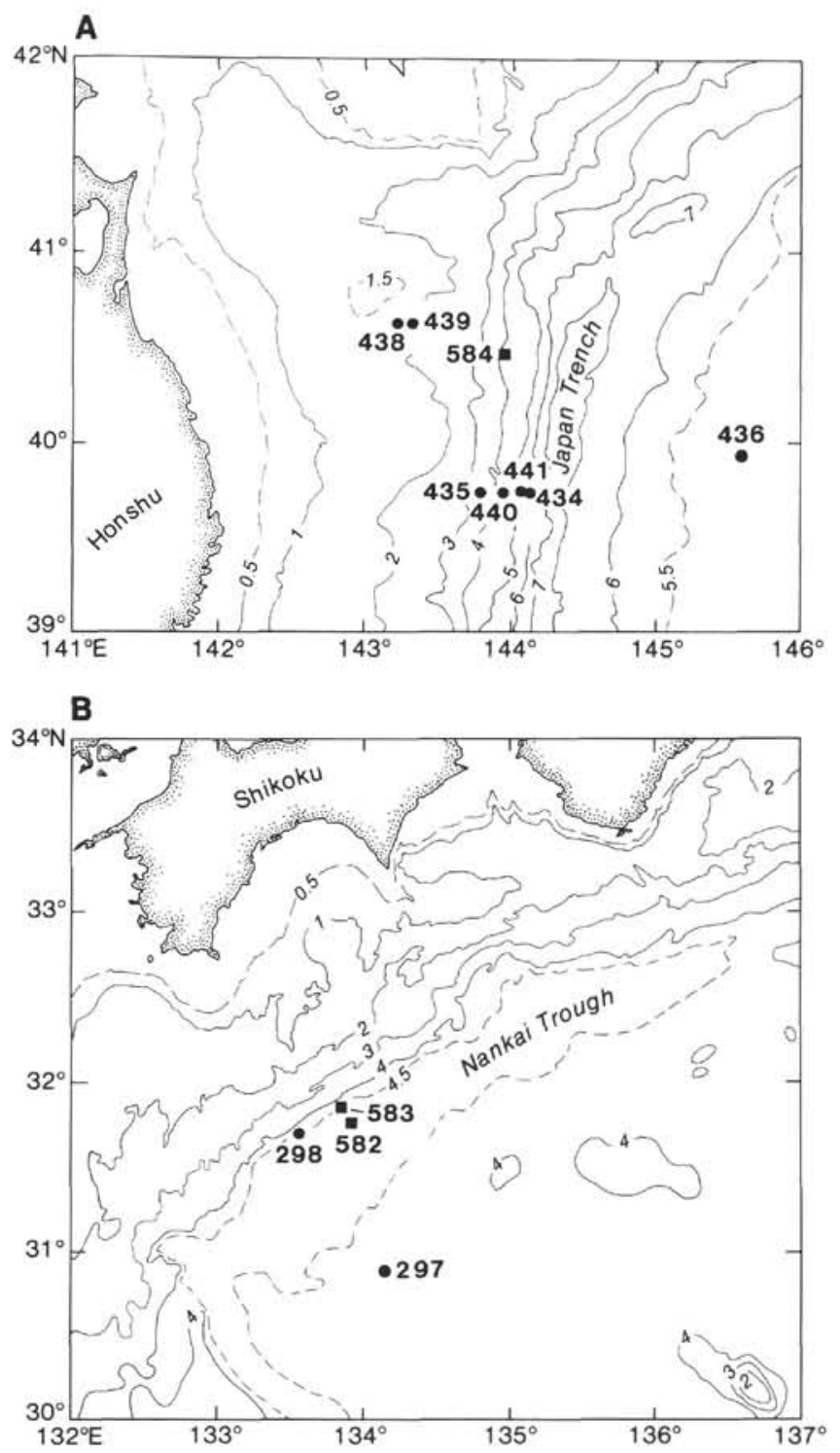

Figure 1. Location of DSDP Leg 87 off Japan; (A) Site 584 and (B) Sites 582 and 583. (Depths in km.)

difference is observed in the chemical and isotopic profiles of the interstitial waters for these two sites. Murata and others (1977) reported an approximate 8\%0 decrease in $\delta^{18} \mathrm{O}$ values of silica minerals (from +37 to $+29 \%$ ) during diagenetic recrystallization of diatom frustules to cristobalitic cherts in Monterey Shale (California). If an isotopic exchange reaction has taken place between the interstitial water and the siliceous sediment, the ${ }^{18} \mathrm{O} /$ ${ }^{16} \mathrm{O}$ ratios of the interstitial waters at Site 584 would increase with depth, or, at least, the rate of decrease with depth might be smaller than that at Site 582. However, this is not the case, and the gradient is larger at Site 584. Exchange reaction with siliceous material is, therefore, not important in the compositional change of the interstitial waters at Site 584. In fact, the biogenic opal-rich sediment of the Site 584 cores shows no indication of recrystallization even at the deepest levels (Matsumoto et al., this volume). The smaller ${ }^{18} \mathrm{O} /{ }^{16} \mathrm{O}$ and $\mathrm{Mg}^{2+}$ gradients at Site 582 are attributed to weaker reaction with
Table $1 .{ }^{18} \mathrm{O} /{ }^{16} \mathrm{O}$ ratios of interstitial waters of DSDP cores at Sites 582, 583, and 584 .

\begin{tabular}{lcc}
\hline $\begin{array}{c}\text { Hole-Core-Section } \\
\text { (interval in cm) }\end{array}$ & $\begin{array}{c}\text { Sub-bottom depth } \\
(\mathrm{m})\end{array}$ & $\begin{array}{c}\delta^{18} \mathrm{O}_{\text {SMOW }} \\
(\% 0)\end{array}$ \\
\hline Site 582 & & \\
& & \\
$582-1-3,143-150$ & 4.5 & +0.34 \\
$582-3-5,120-130$ & 26.9 & +0.48 \\
$582 \mathrm{~B}-2-2,140-150$ & 61.2 & +0.26 \\
$582 \mathrm{~B}-14-5,138-150$ & 181.5 & +0.04 \\
5822-23-1, 140-150 & 262.2 & +0.04 \\
$5822-38-3,140-150$ & 408.3 & -0.17 \\
5822-50-3, 135-150 & 522.3 & -0.47 \\
582B-66-2, 135-150 & 674.8 & -0.27
\end{tabular}

Site 583

$\begin{array}{lrl}583-2-5,140-150 & 13.0 & -0.31 \\ 583-3-5,140-150 & 22.5 & -0.31 \\ 583-5-4,135-150 & 40.0 & -0.65 \\ 583-17-2,130-150 & 110.0 & -0.80 \\ 583 \mathrm{~B}-2-3,140-150 & 9.5 & +0.17 \\ 583 \mathrm{~B}-5-2,135-150 & 23.0 & +0.09 \\ 583 \mathrm{C}-2-3,135-150 & 34.5 & +0.20 \\ \text { 583C-4-2, 135-150 } & 46.0 & +0.37 \\ \text { 583D-9-2, 135-150 } & 126.7 & -0.30 \\ \text { 583D-14-2, 135-150 } & 175.0 & -0.22 \\ \text { 583D-22-4, 135-150 } & 255.3 & -0.45 \\ \text { 583F-6-2, } 135-150 & 201.7 & -0.79 \\ \text { 583F-12-1, 140-150 } & 257.8 & -0.79 \\ \text { 583F-17-1, 135-150 } & 306.1 & -0.52 \\ \text { 583F-18-3, 135-150 } & 318.7 & -0.86 \\ \text { 583G-7-4, 135-150 } & 370.7 & -1.11 \\ \text { 583G-12-1, 135-150 } & 414.6 & -0.71 \\ \text { 583G-14-2, 10-15 } & 433.8 & -1.42\end{array}$

Site 584

$\begin{array}{lrr}584-1-4,140-150 & 4.0 & +0.21 \\ 584-3-3,140-150 & 24.5 & +0.61 \\ 584-6-2,140-150 & 51.2 & +0.52 \\ 584-7-1,140-150 & 59.3 & +0.35 \\ 584-10-3,140-150 & 91.0 & +0.40 \\ 584-16-2,135-150 & 147.0 & +0.29 \\ 584-19-6,135-150 & 182.1 & +0.14 \\ 584-27-4,135-150 & 255.8 & -0.12 \\ 584-32-2,135-150 & 300.3 & -0.14 \\ 584-37-5,135-150 & 352.6 & -0.24 \\ 584-42-4,135-150 & 398.9 & -0.50 \\ 584-47-3,135-150 & 445.5 & -0.55 \\ 584-51-2,135-150 & 482.3 & -0.64 \\ 584-57-3,135-150 & 541.1 & -0.75 \\ 584-62-4,135-150 & 590.1 & -0.86\end{array}$

Note: SMOW $=$ standard mean ocean water

the younger unconsolidated sediments. The coarse-grained turbidites at Site 582 would also prevent an effective mineral-water interaction.

A small increase in $\delta^{18} \mathrm{O}$ up to $+0.6 \%$ is observed at about $25 \mathrm{~m}$ sub-bottom depth in the cores at Sites 582 and 584 (Figs. 2, 4). If a negative $\delta^{18} \mathrm{O}$ value for the ocean bottom water (Epstein and Mayeda, 1953) is assumed, the magnitude of the increase would be even greater. Because no particular layer enriched in a specific mineral is identified at this depth at either site, this increase in ${ }^{18} \mathrm{O}$ may not have been produced by reaction with minerals, but more likely by ${ }^{18} \mathrm{O}$ enrichment of the residual solution by dewatering of sediments and ultrafiltration by compacted clays (Coplen and Hanshaw, 1973). A small increase in salinity up to $36.6 \%$ at the same sub-bottom depth at Site 584 (see site Chapter, Site 584 , this volume) seems to support the ultrafiltration 


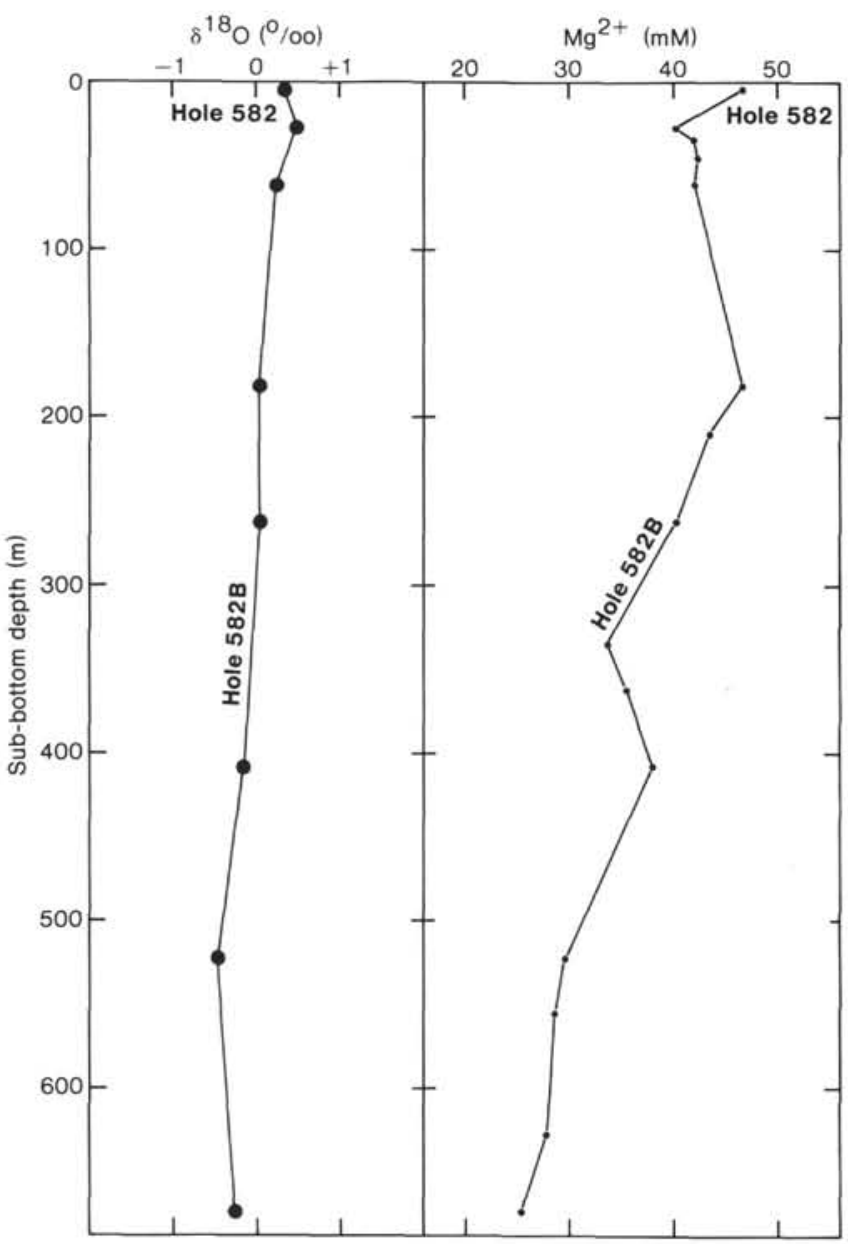

Figure 2. $\delta^{18} \mathrm{O}$ and $\mathrm{Mg}^{2+}$ variation of interstitial waters with depth at Site $582 . \mathrm{Mg}^{2+}$ values from Site 582 chapter (this volume).

mechanism. The correlation between the ${ }^{18} \mathrm{O} /{ }^{16} \mathrm{O}$ and salinity gradients is not clear at Site 582 . The $\delta^{18} \mathrm{O}$ maximum could occur at a certain depth as a result of the balance of mineral-water interaction and ultrafiltration processes. The depth of the $\delta^{18} \mathrm{O}$ maximum may depend upon the degree of consolidation of sediments and kinds of minerals formed.

At Site 583, located in deformed sediments in the basal thrust sheet, the $\delta^{18} \mathrm{O}$ values of the interstitial waters do not steadily decrease with depth as they do in the undeformed sediments at Sites 582 and 584 (Fig. 3). Even an increase in ${ }^{18} \mathrm{O} /{ }^{16} \mathrm{O}$ with depth, being in agreement with the $\mathrm{Mg}^{2+}$ increase, occurs in Holes 583B and 583C. If this anomalous profile resulted from disturbance of the once-formed stratification of the sediments, then the deformation rate of the sediments must be greater than the reaction rate in order to attain a steady state of the interstitial water-mineral interaction.

Alternatively, the local high- $\delta^{18} \mathrm{O}$ zones in the profiles are produced by a temperature increase that might take place in strongly sheared zones. The seismic reflection profile indicates that the thrust surface crosses Hole 583D near $160 \mathrm{~m}$ sub-bottom and that a hanging-wall splay intersects Hole 583D near $60 \mathrm{~m}$ sub-bottom (Leg 87 Scientific Party, 1983). However, no definitive evidence of

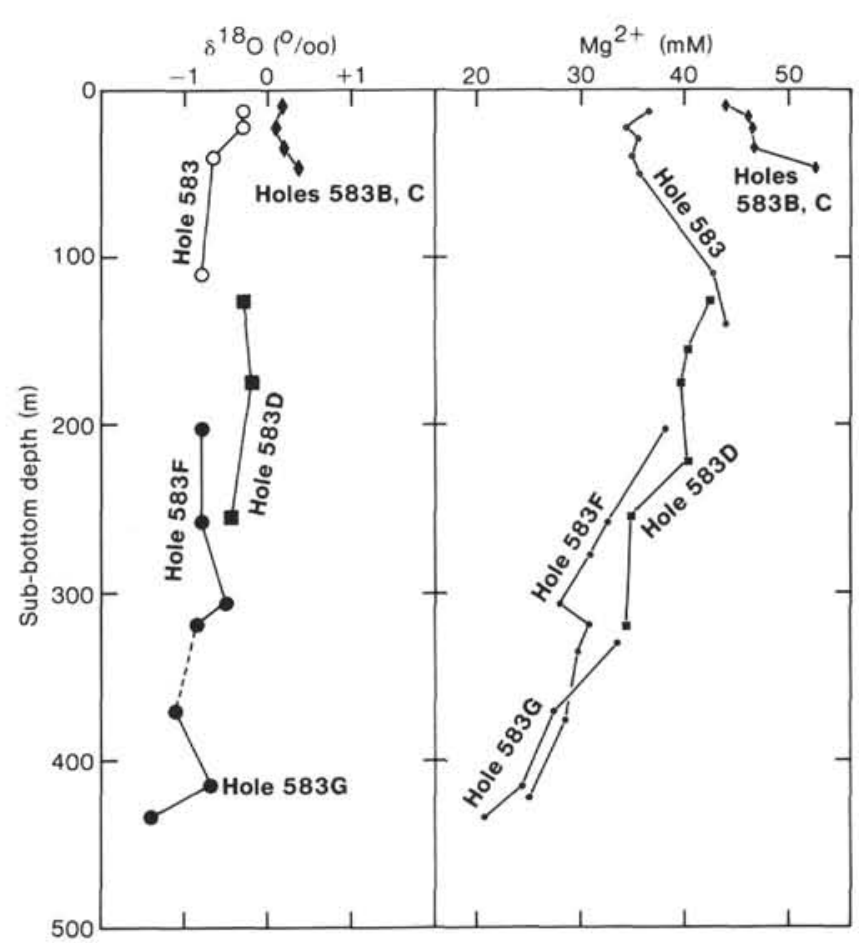

Figure $3 . \delta^{18} \mathrm{O}$ and $\mathrm{Mg}^{2+}$ variation of interstitial waters with depth at Site $583 . \mathrm{Mg}^{2+}$ values from Site 583 chapter (this volume).

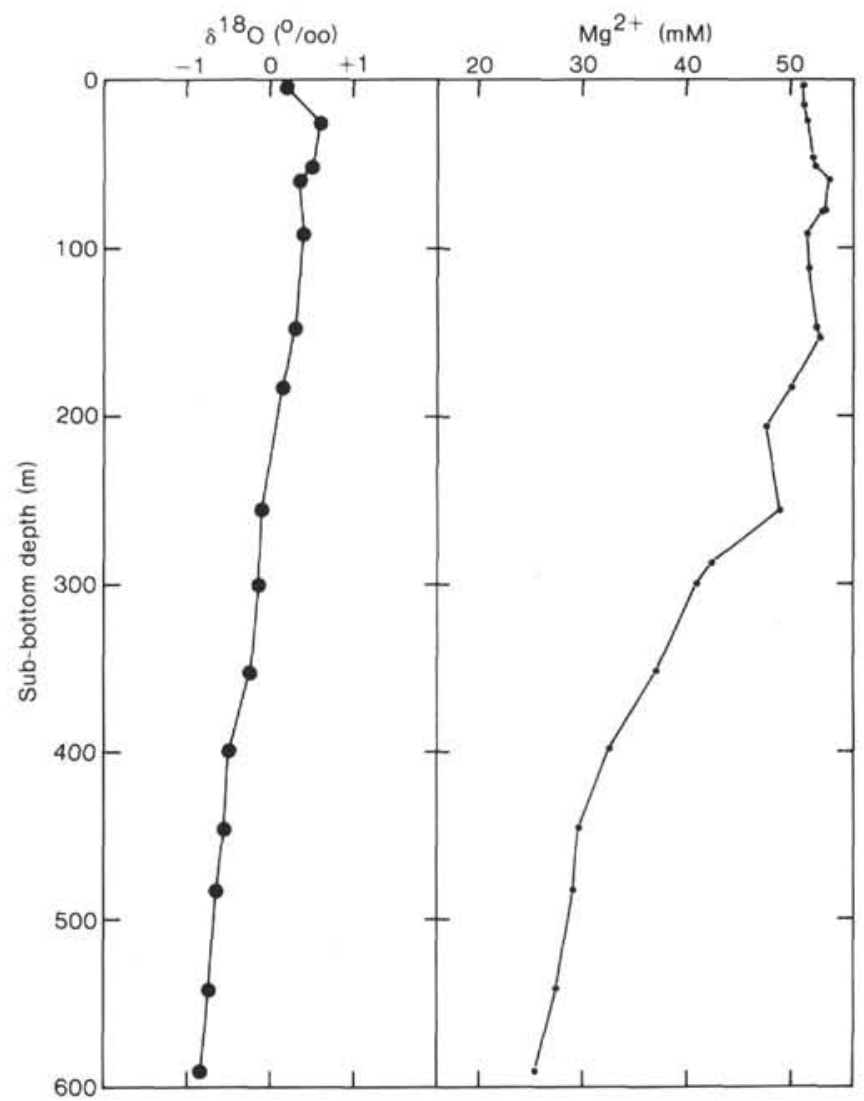

Figure 4. $\delta^{18} \mathrm{O}$ and $\mathrm{Mg}^{2+}$ variation of interstitial waters with depth at Hole $584 . \mathrm{Mg}^{2+}$ values from Site 584 chapter (this volume). 
strongly sheared zones has yet been found at the depths corresponding to these cores.

\section{ACKNOWLEDGMENTS}

We are grateful to Drs. Karlis Muehlenbachs and Hsueh-Wen Yeh for reviewing the manuscript.

\section{REFERENCES}

Coplen, T. B., and Hanshaw, B. B., 1973. Ultrafiltration by a compacted clay membrane-I. Oxygen and hydrogen isotopic fractionation. Geochim. Cosmochim. Acta, 37:2295-2310.

Elderfield, H., Gieskes, J. M., Baker, P. A., Oldfield, R. K., Hawkesworth, C. J., and Miller, R., $1982 .{ }^{87} \mathrm{Sr} /{ }^{86} \mathrm{Sr}$ and ${ }^{18} \mathrm{O} /{ }^{16} \mathrm{O}$ ratios, interstitial water chemistry and diagenesis in deep-sea carbonate sediments of the Ontong Java Plateau. Geochim. Cosmochim. Ac$t a, 46: 2259-2268$.

Epstein, S., and Mayeda, T., 1953. Variation of $\mathrm{O}^{18}$ content of waters from natural sources. Geochim. Cosmochim. Acta, 4:213-224.

Gonfiantini, R., 1984. Advisory group meeting on stable isotope reference samples for geochemistry and hydrological investigations.
Report to the Director General, International Atomic Energy Agen$c y$, Vienna.

Karig, D. E., Kagami, H., and DSDP Leg 87 Scientific Party, 1983. Varied responses to subduction in Nankai Trough and Japan Trench forearcs. Nature, 304:148-151.

Lawrence, J. R., Drever, J. I., Anderson, T. F., and Brueckner, H. K., 1979. Importance of alteration of volcanic material in the sediments of Deep Sea Drilling Site 323: chemistry, ${ }^{18} \mathrm{O} /{ }^{16} \mathrm{O}$ and ${ }^{87} \mathrm{Sr} /$ ${ }^{86}$ Sr. Geochim. Cosmochim. Acta, 43:573-588.

Lawrence, J. R., Gieskes, J. M., and Broecker, W. S., 1975. Oxygen isotope and cation composition of DSDP pore waters and the alteration of Layer II basalts. Earth Planet. Sci. Lett., 27:1-10.

Leg 87 Scientific Party, 1983. Leg 87 drills off Honshu and SW Japan. Geotimes, 28(1):15-18.

Murata, K. J., Friedman, I., and Gleason, J. D., 1977. Oxygen isotope relations between diagenetic silica minerals in Monterey Shale, Temblor Range, California. Am. J. Sci., 277:259-272.

Date of Initial Receipt: 4 June 1984

Date of Acceptance: 3 October 1984 